
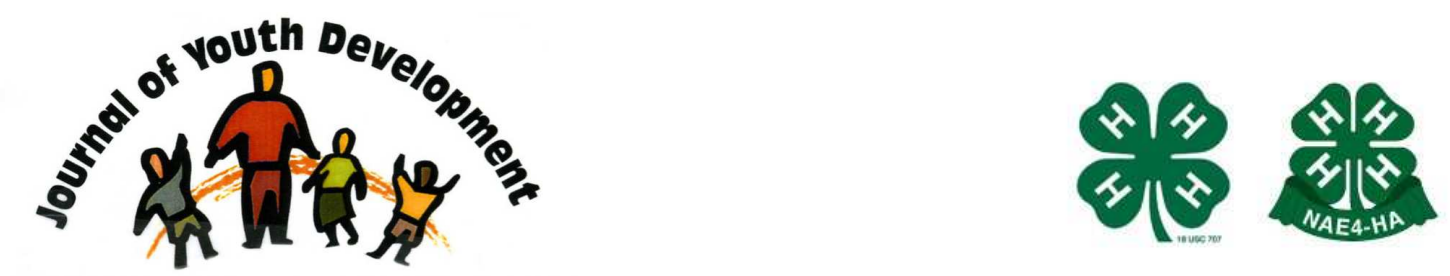

Bridging Research \& Practice

\title{
Modern Rap Music: Mining the Melodies for Mental Health Resources
}

\author{
Jaleel K. Abdul-Adil \\ Department of Psychiatry \\ University of Illinois at Chicago \\ Chicago, IL \\ jabdul@psych.uic.edu
}




\title{
JOURNAL OF YOUTH DEVELOPMENT \\ bridging research and practice

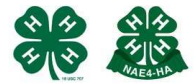

Volume 9, Number 2, Summer

Article 140902RR001

\section{Modern Rap Music: Mining the Melodies for Mental Health Resources}

\author{
Jaleel K. Abdul-Adil \\ University of Illinois at Chicago
}

\begin{abstract}
Modern Rap music is a very popular, powerful, and controversial form of contemporary youth media. Despite clearly counter-productive aspects of certain lyrics, videos, and other cultural elements, Rap music also offers prosocial material that can enhance the appeal and impact of mental health interventions. This article describes the Young Warriors program as an example of a Rap-based program that promotes positive development in urban ethnic minority youth. Future directions and similar scholarly efforts are also highlighted.
\end{abstract}

\section{Introduction}

\section{Modern Rap Music and Hip-Hop Culture}

One of the most popular yet controversial forms of contemporary youth media is modern Rap music. Since its inception in the mid-1970s amid a dynamic community-based collective of music, arts, and dance among urban youth in New York, Rap music and its related Hip-Hop culture (comprised of MCs, DJs, break-dancers, graffiti art, and beat-boxing) has grown into a diverse multicultural phenomenon and global multibillion dollar industry that is one of the most popular musical genres among youth and adolescents around the world (Business Wire, 2011). Beyond its musical preeminence, Rap music and Hip-Hop also heavily influence language, clothing, hairstyles, mannerisms, social interactions, and other forms of cultural identifications and expressions among a vast majority of contemporary youth, especially urban AfricanAmericans, Latinos, and other ethnically diverse groups.

\section{Beyond "Broad Brushes"}

Despite its undeniable appeal among youth, Rap music and Hip-Hop culture have also endured a significant amount of criticism from mainstream media and concerned parents about negative lyrical content (Daykin, De Viggiani, Pilkington, \& Moriarty, 2012). The bulk of anti-Rap concerns center on the profane lyrics, violent images, misogynous themes, and criminal activities that appear to be "glorified" and "romanticized" in many Rap songs, particularly the 
so-called Gangsta Rap genre. Although these concerns about explicit and illegal content of certain songs justify continued caution about impressionable youth being exposed to negative content, Rap music also has an equally prominent prosocial subgenre called Radical Rap that advocates positive self-identity and self-development. With these types of juxtaposing genres, Rap music requires a thorough and objective assessment by social scientists, community-based advocates, and other supporters of positive youth development to ascertain any prosocial uses as well as curb any negative impacts of Rap/Hip-Hop. Consequently, any "black and white" thinking of Rap music being either "all good" or "all bad" both: 1) belies the complexity and diversity of this vast musical form; and 2) blocks any sophisticated understanding and potential utilization of a compelling cultural tool.

\section{Mining the Melodies for Mental Health}

A number of contemporary youth providers have begun serious scholarly examination of the role of Rap music as a promising tool for mental health programs promoting positive youth development (Hadley, \& Yancy, 2011). Congruent with music therapy and other creative arts program models, Rap-based youth programs use lyrical analyses, video critiques, current events examples, and facilitated peer discussions to engage and motivate participants to share views and align behaviors toward positive development (Abdul-Adil, 2006; Elligan, 2004; Tyson, 2011; Winfrey, 2009).

An example of a Rap-based program that promotes prosocial development of ethnic minority urban youth is the Young Warriors program (Abdul-Adil, 2006; Watts, \& Abdul-Adil, 1998; Watts, Abdul-Adil, \& Pratt, 2002). The Warriors program model uses "critical consciousness" (e.g., critical thinking skills) to analyze video content, discuss daily relevance, and plan personal application of the selected Rap songs. A typical Warrior program session would employ a variety of songs to serve the program goals ranging from a "positive" Rap video like Lupe Fiasco's "Around My Way (Freedom Ain't Free)" encouraging social and civic responsibility to a "negative" Rap song like 50 Cent's "Many Men (Wish Death)" admonishing self-destructive violence and drug involvement. Rather than rehashing traditional mental health approaches that often fail to effectively reach many urban youth, the Warriors model uses the appeal and content of selected Rap songs to illustrate and punctuate prosocial points in youth programming.

\section{Future Directions}

While remaining vigilant about possible negative impacts of certain Rap songs, scholarly youth development advocates are expanding prosocial uses of selected modern Rap music and related Hip-Hop culture. A number of new efforts are underway, including the recently-established Hip Hop Psychology and its annual One Mic conference to gather researchers, practitioners, and policy makers across North America for collaborative efforts at establishing empirically-based and methodologically-rigorous approaches to Rap-based youth programming. These novel efforts may hopefully identify additional tools to engage in creative methods of getting beyond the madness of youth media to develop engaging and effective prosocial programs. 


\section{References}

Abdul-Adil, J.K. (2006). Rap Music \& Urban Rhapsody: Violence Prevention for Inner-City African American Male Adolescents. The Journal of Urban Youth Culture, 4(1).

Business Wire. (2011). The Nielsen Company \& Billboard's 2010 Music Industry Report. Retrieved from http://www.businesswire.com/news/home/20110106006565/en/NielsenCompanyBillboard\%E2\%80\%99s-2010-Music-Industry-Report.

Daykin, N., De Viggiani, N., Pilkington, P., \& Moriarty, Y. (2012). Music making for health, wellbeing and behaviour change in youth justice settings: a systematic review. Health Promotion International.

Elligan, D. (2004). Rap Therapy: A practical guide for communicating with young adults through Rap Music. New York: Kensington Publishing Corporation.

Hadley, S.J., \& Yancy, G. (Eds.). (2011). Therapeutic uses of rap and hip hop. BrunnerRoutledge.

Tyson, E. (2011). Hip-Hop Healing: Rap Music in Grief Therapy with an African American Adolescent Male. In S. Hadley, \& G. Yancy. (Eds.). Therapeutic Uses of Rap and Hip-Hop (pp. 293-305). New York: Routledge.

Watts, R.J., Abdul-Adil, J., \& Pratt, T. (2002). Sociopolitical and civic development in young African American men: A psychoeducational approach. Psychology of Men and Masculinity, 3(1), 41-50.

Watts, R., \& Abdul-Adil, J. (1998). Promoting critical consciousness in young, African American men. In R. Watts \& R. Jagers (Eds.) Manhood Development in Urban, African-American Communities. Journal of Prevention \& Intervention in the Community, 16(1), 63-86.

Winfrey, A.M. (2009). H.Y.P.E.: Healing Young People Thru Empowerment. African-American Images.

(C) Copyright of Journal of Youth Development Bridging Research and Practice. Content may not be copied or emailed to multiple sites or posted to a listserv without copyright holder's express written permission. Contact Editor at: patricia.dawson@oregonstate.edu for details. However, users may print, download or email articles for individual use.

ISSN 2325-4009 (Print); ISSN 2325-4017 (Online) 